University of Louisville

ThinkIR: The University of Louisville's Institutional Repository

Faculty Scholarship

Fall 2007

\title{
James Slevin and the identifying practices of composition.
}

Bruce Horner

University of Louisville, horner.bruce@gmail.com

Follow this and additional works at: https://ir.library.louisville.edu/faculty

Part of the English Language and Literature Commons, and the Rhetoric and Composition Commons

Original Publication Information

This article was originally published in ADE Bulletin, number 143, in Fall 2007.

This Article is brought to you for free and open access by ThinkIR: The University of Louisville's Institutional Repository. It has been accepted for inclusion in Faculty Scholarship by an authorized administrator of ThinkIR: The University of Louisville's Institutional Repository. For more information, please contact thinkir@louisville.edu. 


\title{
James Slevin and the Identifying Practices of Composition
}

\author{
BRUCE HORNER
}

\section{IN THIS essay, I wish to} locate James Slevin's scholarship in the context of ongoing debates about composition's identity. That debate is sometimes couched in terms of the relation between something called composition and something called rhetoric, but it is also couched in terms of whether composition is a field, an academic discipline, or a teaching profession. It is further complicated by competing understandings of what any of these terms might mean.

I argue that Slevin's scholarship represents both a more immediately practical approach to defining composition's identity and, simultaneously, a more utopian response to the situation in which people I term compositionists find themselves than more dominant approaches to identifying what composition means or should mean. All approaches to defining composition's identity, Slevin's included, can be distinguished from one another by both historiographic method and the entity that the adopted method constructs as the subject, as it were, of composition. For example, Robin Varnum's Fencing with Words: A History of Writing Instruction at Amherst College during the Era of Theodore Baird, 1938-1966 can be understood as based on the premise that composition's identity inheres in specific traditions of teaching practices-including not only readings but also assignments, ways of marking student texts, ways of talking about all these in classrooms, and the staffing, students, and interactions of all those engaged in these activities. That premise accounts in part for the methodology of archival research at a specific institution-in Varnum's case, research on the unpublished documents from almost thirty years of coursework at Amherst College as well as interviews with its English 1-2 students and teachers. By contrast, Joseph Harris's A Teaching Subject: Composition since 1966, while clearly committed to the importance of such traditions of teaching, focuses not on documenting such practices-a task involving archival research-but on the problematics of a set of terms (growth, voice, discourse community, contact zone, error) that have dominated the public discourse produced by and for academics concerning themselves with those practices. Unlike both of these studies, James Berlin's histories of composition focus less on either the explicit terms with which such academics debate composition or on the traditions of practice at particular institutions than on identifying the ideologies ostensibly governing both those terms and those traditions.

There is value in all these approaches. Following Berlin, composition teachers and scholars have had to rethink how they understand the aims of their work and the terms in which they describe that work. Following Varnum, they found it harder to speak so blithely about the dominance of currenttraditional rhetoric in the early and mid twentieth century. Following Harris, teachers could not so readily imagine their task to be encouraging students' own voice, say, or initiating students into the academic discourse community.

While all this scholarship has helped elaborate our understanding of composition, other composition scholarship has focused on attempting to account for two ongoing concerns facing all those

The author is professor of English and Endowed Chair in Rhetoric and Composition at the University of Louisville. A version of the article was presented at the 2007 Conference on College Composition and Communication in New York City at a session honoring the life and work of James F. Slevin, 1945-2006.

ADE Bulletin, No. I43, Fall 2007

(C) 2007 By THE ASSOCiATION OF DEPARTMENTS OF ENGLish 
involved in composition - the exploitation of those assigned to teaching composition and the low academic institutional status of composition programs, especially in relation to English departments within which many such programs are housed. Let me offer two admittedly broad and sweeping generalizations about some of this work. First, much of it can be characterized as functionalist: that is, it argues that work going by the name of teaching composition has a particular function it plays within society. This argument is accomplished by renaming particular historical effects of some composition programs-for example, the tracking of students or the teaching of general writing skills — as their function (see Petraglia; Shor). Official statements taken from historical documents about the role composition is to play are taken as a revelation of the role it is both assigned to and does play socially. Moreover, later work in composition is viewed as irremediably determined by the roles officially assigned to it earlier at, for example, Harvard (see Crowley). The contrast between this approach and that focusing on teaching practices is perhaps best illustrated by the role that textbooks are imagined to play. Whereas scholarship I have been naming functionalist treats textbooks as revelatory of the beliefs and practices of composition teachers, the approach described earlier identifying composition with teaching practices treats textbooks as only one out of many sources of evidence for the kind of work carried out in composition, limited in failing to recognize what teachers and students have done with and to the textbooks, whatever their official purposes.

Second, insofar as this work identifies composition in terms of purposes officially assigned to it, it calls for improving the status of composition and its workers by eliminating its ties with those purposes and realigning it with the official purposes assigned to other academic enterprises, such as cultural studies or the long tradition of rhetorical study. For example, if composition's ties to firstyear required composition courses were eliminated, it is imagined by some that composition's status, and the treatment of those teaching composition, would improve (see Crowley). Or if composition were redefined as cultural studies instead of the teaching of writing skills, others suggest, composition would be more exciting to teach and to take, and its academic status would also rise.

As I have discussed elsewhere, these arguments occlude the actual teaching practices in which those erstwhile laborers engage, as well as the work students accomplish, through mistaking official representations of that work-in official definitions of composition, its teachers, and its students and in textbooks - for the full range of activities and desires pursued (122-32). In such arguments, the history of composition is one in which teachers and students are acted on rather than acting, the objects but not subjects of history. Finally, in such histories, the range of possible alternatives is limited to those already present on the scene-disciplines that are more established, or seemingly more established, for composition to emulate. They thus ultimately support the academic institutional status quo.

Slevin's work is distinguished from this other scholarship by the specific identifying practices it engages in to name what the work of composition has been, is, and should be. Those practices do not include much archival research into specific practices in teaching composition other than his own. They share with work like Harris's a sharp, critical interrogation of the terms by which the work of composition is named and the consequences of those terms in defining, and often, limiting, such work and its valuation. Slevin, however, is concerned less with the discursive practices of those affiliated with composition in, say, scholarship than with institutional discursive practices and, in particular, those that are seemingly the most mundane and, therefore, simultaneously least acknowledged and most powerful - the discourse of course listings, letters of offer, MLA job postings, and the reports of professional organizations like the MLA and the American Association for Higher Education (AAHE). I'm thinking here of Slevin's critique in "Connecting English Studies" of the MLA's "Report on the Future of the Profession," but also his critique of the discourse of departmental curricula in "Depoliticizing and Politicizing Composition Studies" and of compositionists' own pursuit of disciplinary status in "Disciplining Students: Whom Should Composition Teach and What Should They Know?"

Slevin's critiques of the ordinary terms - that is to say, dominant and dominating-used to describe composition put him at odds with both academics and those who attempt to administer them. I believe this is partly what has earned him a reputation of being something of a maverick or iconoclast, as suggested by the title of one of his chapters in Introducing English: "The Impolitics of Letters: Undoing Critical Faculties." There he critiques 
the amalgamation of "a discourse of commerce and a discourse of community" dominant among AAHE's discussion of tenure, arguing instead that

the most important thing a college or university can do
to assure its own effectiveness is encourage faculty to be
suspicious of its institutional needs and missions, to bring
from their engagement with the demands of disciplinary
work those doubts, questions, and discoveries that are not
marshaled by, or in the service of, the institution ... to pos-
itively encourage autonomy and resistance.
$(236,238)$

Slevin identifies the defining feature of universities, as opposed to what he disparagingly calls "diploma markets," to be "the critical examination of the truthfulness of knowledge created, received, and exchanged" (235). And it is fair to say that, true to his ideals, Slevin's writing enacts just such critical examination, autonomy and resistance, and suspicion of institutional needs and missions.

Slevin's writing, however, is also distinguished from common versions of the discourse of critique that ultimately cede full agency to the anonymous hegemony of institutions and society. That is to say, unlike those approaches I've termed functionalist, Slevin does not allow his attention to the limiting definitions posed in dominant representations of composition to occlude recognition of the full range of actual as well as possible work conducted in the name of composition or, for that matter, the academy. For example, while he identifies composition with the project of colonization and its narratives of improving natives through conversion (Introducing 6), he also recognizes composition as the site where what he identifies as the most important intellectual work of the academy can take place: "working collaboratively with students and colleagues to interpret educational practices and to work for educational reform" (Introducing 2).

I want to briefly discuss three features of his arguments that illustrate the particular character of his contributions to debates about composition's identity. First and foremost, Slevin identifies composition in terms of the students in the classroom. Not only does he recognize students as possessing agency. He argues, in fact, that the revitalization of composition teaching that he claims took place with open admissions "was in profound ways made possible by the presence and intellectual energy of students who questioned the hegemony of received ways of reading and writing" (Introducing 2). The story he tells in his book Introducing English of how he himself came to composition is a story of the "disruption of [his] certainties about reading" brought on by his encounters with his students (27). This story is quite different from the standard account of how open admissions changed composition. That account tells of the appearance of a new breed of student, the "basic writer," whose unheard-of needs represented a frontier in the science of teaching composition that spawned the development of entirely new methods of teaching. In Slevin's accounts, by contrast, composition is not a "field" or "discipline," at least not as ordinarily understood with experts training the laity. Instead, he says, it is "an intellectual and social movement responding to the difficulties created by institutional practices that undermined the very purposes of a university" (Introducing 38). Slevin's identification of the work of composition as an activity involving students working collaboratively with teachers on writing puts him at odds with attempts to assign academic disciplinary status to composition, since, as he explains, those attempts "buy into a conceptual framework that makes every effort to change things — even just to see things clearly_impossible [and] plac[es] those of us interested in teaching at a serious disadvantage" ("Disciplining" 158). Efforts to define composition in terms of its disciplinarity are either doomed to failure, given composition's identification with teaching, or they will transform composition into something unrecognizable, a discipline in which teaching is peripheral, not central.

A second distinguishing feature of Slevin's work is in his insistence that composition teaching itself is what he repeatedly calls "intellectual work." The phrase "intellectual work" is invoked repeatedly in Introducing English, to name both the real and ideal identity and charge of composition. While in some sense this phrase might seem unobjectionable-at least to those identifying themselves as intellectual-Slevin's use of it to name what composition is about is distinctive. For by "intellectual work" he refers only infrequently to what is ordinarily understood by that phrase-the development of graduate programs in rhetoric and composition and the published scholarship of the faculties affiliated with such programs. Instead, he uses the phrase to name what goes on in first-year undergraduate writing courses and, more specifically, the work accomplished by first-year students. He claims that work not as preparatory to work that might ordinarily be recognized as intellectual but as already 
intellectual, if only we learned to recognize it as such: as an encounter with difficulty and difference not defined and dismissed as deficit. At the same time, though he identifies students as fomenting institutional change by their presence, his characterization of the intellectual work he sees students and their teachers as engaged in invokes traditional ideals of intellectual work as "the critical examination of the truthfulness of knowledge created, received, and exchanged" (Introducing 235). That is to say, his critiques appear to be aimed not at pushing colleges and universities to pursue more novel arrangements, at least not for the sake of novelty, but instead at reviving at least one version of a traditional conception of university life.

Aligned with this conception of intellectual work is a third characteristic that distinguishes Slevin's identifications of composition, a characteristic that, depending on one's perspective, represents either a weakness or a strength. I myself choose here to admire it if I do not always share it. And that is his faith and hope about what composition might achieve, both at the location of its own work and for the university. Slevin claims not only that composition has "pressed directly and powerfully on the work of other disciplines ... in the area of classroom teaching and the curriculum," making these better and shaping "the way knowledge is configured within undergraduate and even graduate education," but also that composition has "even more to offer" (Introducing 263). While he admits to concern about whether "composition as we know it can survive" what he calls the "culture of improvement" (Introducing 265), he appears to be relatively unconcerned about retaining composition as we know it in favor of pursuing what composition might become. This may be in part because of all that he imagines it might be. In another text, he identifies in the current basement status of composition the promise of its impressive potential. He says it this way:

It seems to me that teachers of writing . . . can bring into being a radical reorganization of the professional hierarchy. The very concerns that locate us at the base or bottom of the prevailing power system need to be elaborated, so that we can alter both the theory and practice of English studies. Our aim, then, should be not simply to resituate ourselves within institutions but, in doing so, to reconceive and reconstruct those institutions.

("Depoliticizing" 10)

At least in these moments, Slevin appears both unimpressed and undeterred with what strikes some of us as the overwhelming intransigence of entrenched academic hierarchies. And so he cheerfully advises the likes of Terry Eagleton, and in fact "everyone in English studies," that they "have much to learn from the work of composition" (Introducing 18990). He imagines, in other words, or at least has an admirable faith and hope in the possibility of, being listened to. That is a faith and hope that not all of us share, at least not all the time. His faith and hope in that possibility account in part for not only the extraordinary energy of his work but also his daring, his willingness to dissent not just from his colleagues in English but also from his colleagues in composition, to call into doubt "all that we take for granted" in order to make it possible for us to become something better. It is a faith and hope that we can answer in reading the work of James Slevin.

\section{Works Cited}

Berlin, James A. Rhetoric and Reality: Writing Instruction in American Colleges, 1900-1985. Carbondale: Southern Illinois UP, 1987.

Writing Instruction in Nineteenth-Century Colleges. Carbondale: Southern Illinois UP, 1984.

Crowley, Sharon. "Composition's Ethic of Service, the Universal Requirement, and the Discourse of Student Need." Journal of Advanced Composition 15 (1995): 227-39.

- "The Perilous Life and Times of Freshman English." Freshman English News 14 (1986): 11-16.

. "A Personal Essay on Freshman English.” PRE/ TEXT 12 (1991): 156-76.

Harris, Joseph. A Teaching Subject: Composition since 1966. Upper Saddle River: Prentice, 1997.

Horner, Bruce. Terms of Work for Composition: A Materialist Critique. Albany: State U of New York P, 2000.

Petraglia, Joseph, ed. Reconceiving Writing, Rethinking Writing Instruction. Mahwah: Erlbaum, 1995.

Shor, Ira. "Our Apartheid: Writing Instruction and Inequality." Journal of Basic Writing 16.1 (1997): 91-104.

Slevin, James F. "Connecting English Studies." College English 48 (1986): 543-50.

- "Depoliticizing and Politicizing Composition Studies." The Politics of Writing Instruction: Postsecondary. Ed. John Trimbur and Richard Bullock. Portsmouth: Boynton, 1991. 1-21.

. "Disciplining Students: Whom Should Composition Teach and What Should They Know?" Composition in the Twenty-First Century: Crisis and Change. Ed. Lynn Z. Bloom, Donald A. Daiker, and Edward M. White. Carbondale: Southern Illinois UP, 1996. 153-65.

- Introducing English: Essay in the Intellectual Work of Composition. Pittsburgh: U of Pittsburgh P, 2001.

Varnum, Robin. Fencing with Words: A History of Writing Instruction at Amberst College during the Era of Theodore Baird, 1938-1966. Urbana: Natl. Council of Teachers of English, 1996. 